\title{
Selected Hydrologic Data for Sand Cove Wash, Washington County, Utah
}

Open-File Report 2004-1328

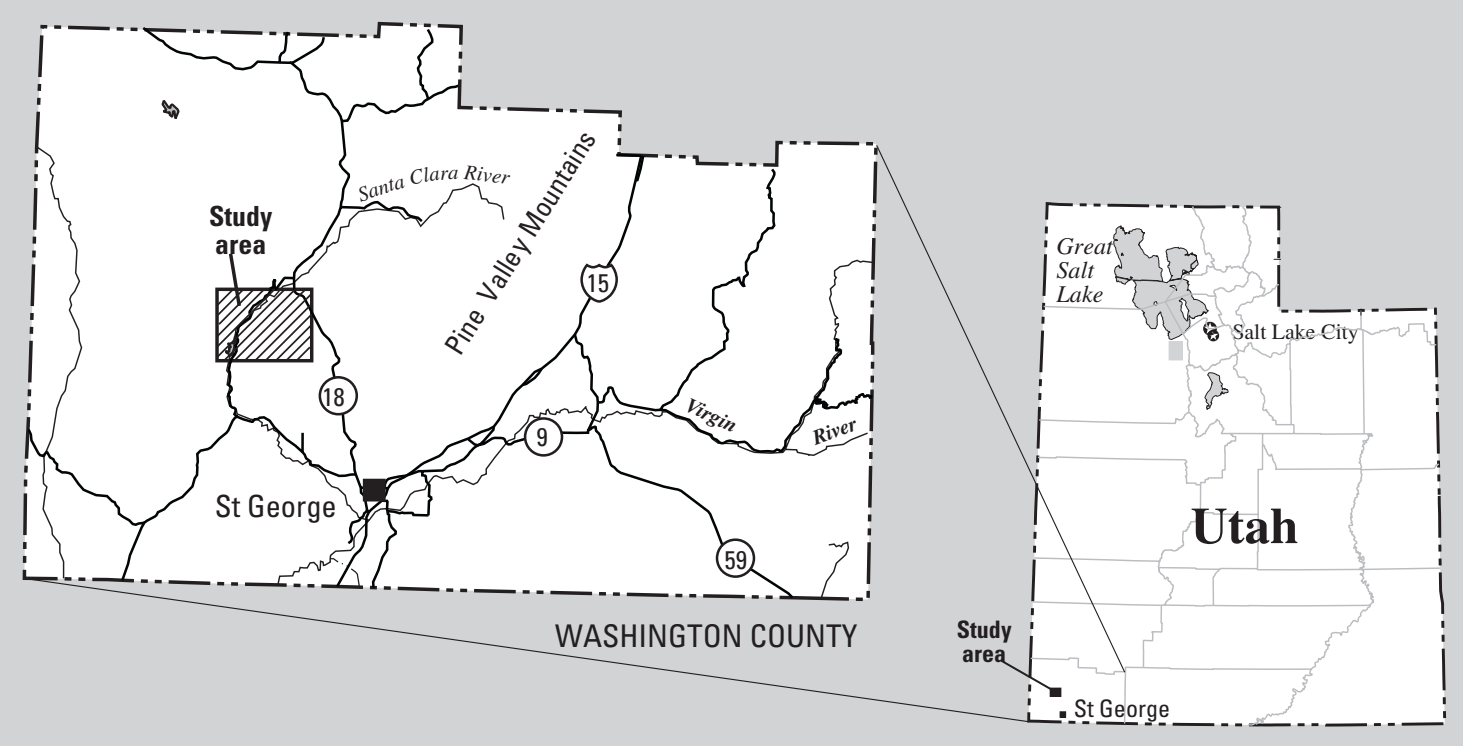

Prepared in cooperation with the Washington County Water Conservancy District 



\section{Selected Hydrologic Data for Sand Cove Wash, Washington County, Utah}

By Aaron Norton and David D. Susong

U.S. GEOLOGIOCAL SURVEY

OPEN-FILE REPORT 2004-1328

PREPARED IN COOPERATION WITH

WASHINGTON COUNTY WATER CONSERVANCY DISTRICT

Salt Lake City, Utah 


\section{U.S. DEPARTMENT OF THE INTERIOR}

GALE A. NORTON, Secretary

\section{U.S. GEOLOGICAL SURVEY}

Charles G. Groat, Director

Any use of trade, product, or firm names in this publication is for descriptive purposes only and does not imply endorsement by the U.S. Government.

For additional information write to:

\section{District Chief}

U.S. Geological Survey

2329 Orton Circle

Salt Lake City, Utah 84119

http://ut.water.usgs.gov
Copies of this report can be purchased from:

U.S. Geological Survey

Branch of Information Services

Building 810

Box 25286, Federal Center

Denver, C0 80225-0286 


\section{CONTENTS}

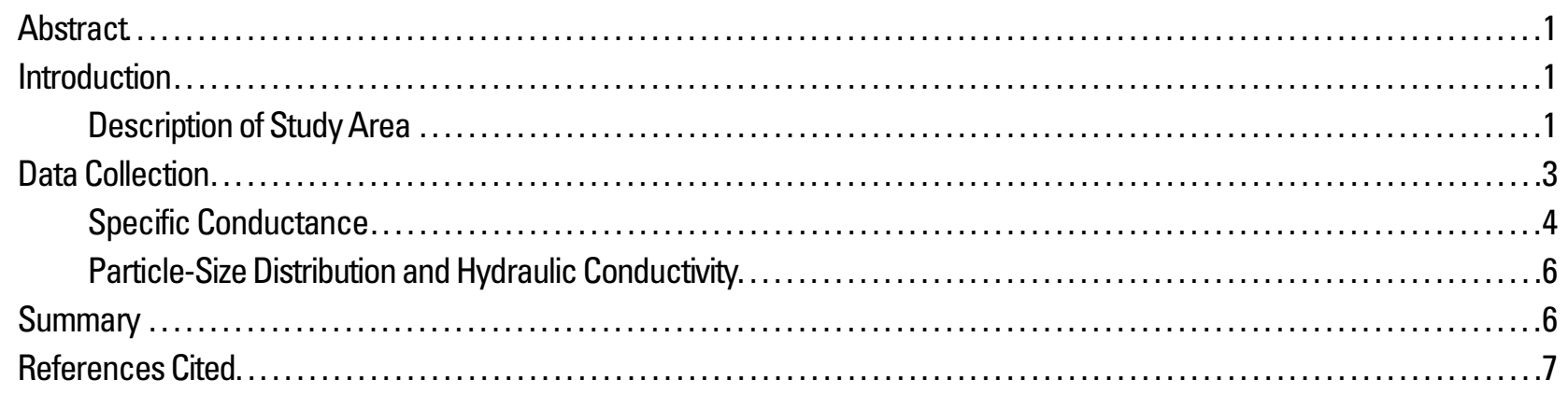

\section{Figures}

Figure 1. Map showing location of boreholes in Sand Cove Wash, Washington County, Utah

Figure 2. Graphs showing relation of depth to specific conductance for leachates from core samples collected in Sand Cove Wash, Washington County, Utah.....

\section{Tables}

Table 1. Lithologic logs of selected boreholes in Sand Cove Wash, Washington County, Utah .....................

Table2. Specific-conductance value of leachates from core samples collected in Sand Cove Wash, Washington

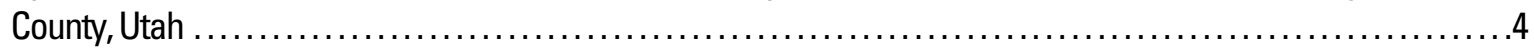

Table3. Particle-size distribution of alluvial deposits along Sand Cove Wash, Washington County, Utah..............6

Table4. Hydraulic properties of core samples collected from unconsolidated deposits in Sand Cove Wash, Washington County, Utah 


\section{CONVERSION FACTORS, DATUMS, AND ABBREVIATED WATER-QUALITY UNITS}

\begin{tabular}{lcl}
\hline Multiply & By & To obtain \\
\hline acre-foot (acre-ft) & 1.213 & cubic meter \\
acre-foot per year (acre-ft/yr) & 1,233 & cubic meter per year \\
foot (ft) & 0.3048 & meter \\
foot per day (ft/d) & 0.3048 & meter per day \\
inch (in.) & 0.0254 & meter \\
mile (mi) & 1.6093 & kilometer \\
pound per square inch $\left(\mathrm{lb} / \mathrm{in}^{2}\right)$ & 703.0695 & kilogram per square meter \\
square mile $\left(\mathrm{mi}^{2}\right)$ & 2.59 & kilometer \\
\hline
\end{tabular}

Temperature in degrees Celsius $\left({ }^{\circ} \mathrm{C}\right)$ may be converted to degrees Fahrenheit $\left({ }^{\circ} \mathrm{F}\right)$ as follows:

${ }^{0} \mathrm{~F}=1.8{ }^{\circ} \mathrm{C}+32$.

Temperature in degrees Fahrenheit $\left({ }^{0} \mathrm{~F}\right)$ may be converted to degrees Celsius $\left({ }^{\circ} \mathrm{C}\right)$ as follows:

$$
{ }^{0} \mathrm{C}=\left({ }^{0} \mathrm{~F}-32\right) / 1.8 .
$$

The permeability of a porous medium is commonly measured in millidarcies. One millidarcy, or 1/1000 darcy, will allow a flow of one milliliter per second of fluid of one centipoise viscosity through one square centimeter under a pressure gradient of one atmosphere per centimeter.

Vertical coordinate information is referenced to the North American Datum of 1929 (NAD29). Horizontal coordinate information is referenced to the North American Datum of 1983 (NAD83).

Specific conductance is reported in microsiemens per centimeter at 25 degrees Celsius $\left(\mu \mathrm{S} / \mathrm{cm}\right.$ at $\left.25^{\circ} \mathrm{C}\right)$. 


\title{
SELECTED HYDROLOGIC DATA FOR SAND COVE WASH, WASHINGTON COUNTY, UTAH
}

\author{
By Aaron Norton and David D. Susong
}

\section{Abstract}

Southwestern Utah is one of the most arid and fastest growing regions of Utah. Development of new and existing water resources will be required to meet the water needs of the region. Sand Cove Wash, a tributary of the Santa Clara River that flows into Gunlock Reservoir, was investigated as a potential site for diverting peak runoff from the Santa Clara River in order to delay its arrival at the reservoir or to artificially recharge alluvial sediment or the underlying Navajo aquifer. Hydrologic data collected in this study are described and listed in this report. Six boreholes were drilled in Sand Cove Wash to determine the vertical and spatial distribution of the alluvial deposits and their hydrologic properties. Nine to 13 feet of fine alluvial sand is underlain by 50 to 70 feet of fine silt and clay. Core samples were analyzed for specific conductance of leachates, particle-size distribution, and saturated vertical hydraulic conductivity. Specific-conductance values of leachates ranged from 23 to 2,940 microsiemens per centimeter. Vertical hydraulic-conductivity values from selected samples ranged from $1.92 \times 10^{-4}$ to 2.5 feet per day.

\section{Introduction}

The population of Washington County, one of the most arid counties of Utah, has been growing rapidly for the past two decades. Ground- and surface-water resources have been extensively developed throughout the county with well fields in the regional Navajo aquifer and reservoirs on the Virgin and Santa Clara Rivers. The Santa Clara River, a tributary of the Virgin River, drains a large watershed that includes the Pine Valley Mountains to the north and east of St. George, Utah (fig. 1).
Runoff to the Santa Clara River from the Pine Valley Mountains exceeds the amount of available storage in Gunlock Reservoir on average every 3 to 4 years. In high runoff years, excess water is spilled from the reservoir. The long-term average annual streamflow above Gunlock Reservoir was 18,070 acre-ft/yr for 19702001 (B. Schlotthauer, Utah Division of Water Rights, written commun., 2004). Computer modeling done by the Utah Department of Water Rights for Gunlock Reservoir for 1970-98 simulated an average annual volume of water spilled of 7,618 acre-ft with a minimum spill of 285 acre$\mathrm{ft}$ and a maximum of 48,812 acre-ft (B. Schlotthauer, Utah Division of Water Rights, written commun., 2004).

The creek in Sand Cove Wash is an ephemeral tributary to the Santa Clara River and discharges into the eastern side of Gunlock Reservoir. Water diverted from the Santa Clara River into Sand Cove Wash using existing infrastructure could artificially recharge alluvial sediments, thereby temporarily storing or delaying the peak snowmelt runoff and artificially recharging the underlying regional Navajo aquifer. The Washington County Water Conservancy District, U.S. Bureau of Reclamation, and U.S. Geological Survey conducted a cooperative hydrogeologic study of Sand Cove Wash to evaluate the potential of diverting peak runoff from the Santa Clara River into Sand Cove Wash for temporary storage. This report compiles selected hydrologic data collected during the study of Sand Cove Wash, including borehole lithologic logs, particle-size analyses of borehole samples, laboratory-determined saturated vertical hydraulic-conductivity values of alluvial wash sediments, and specific-conductance values of core leachates. Complete results of the study are reported in Norton (2004).

\section{Description of Study Area}

Sand Cove Wash (fig. 1) is located about $30 \mathrm{mi}$ northwest of the city of St. George in southwestern Utah. The drainage basin covers about $9 \mathrm{mi}^{2}$ and the wash is about $8.5 \mathrm{mi}$ in length. 


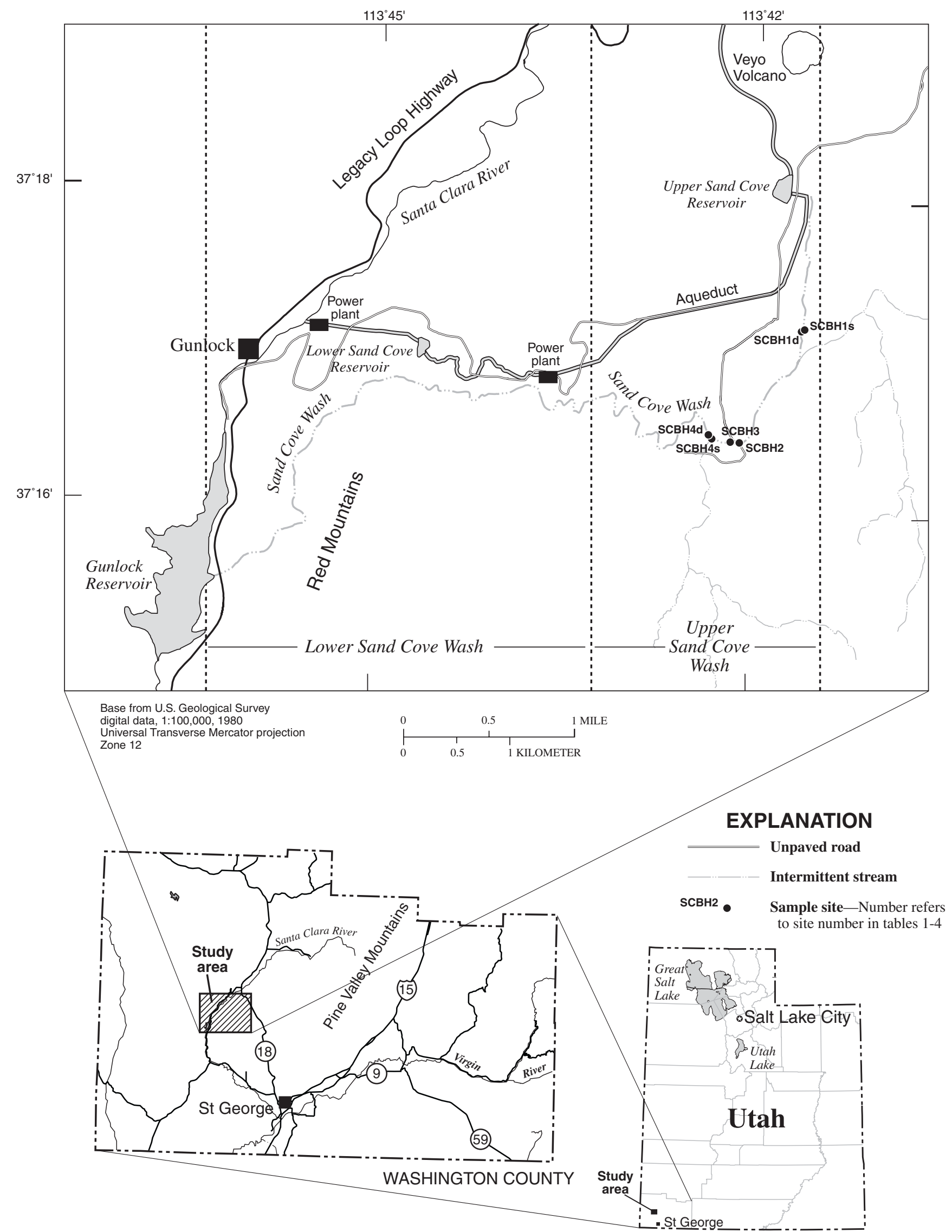

Figure 1. Location of boreholes in Sand Cove Wash, Washington County, Utah. 
The wash can be divided into two parts on the basis of topography and geomorphology (Norton, 2004). The upper part of the wash is about half a mile in width and is relatively flat. Two major tributaries discharge into the upper part, and the channel is underlain by unconsolidated sand and basalt cobbles. The lower part of the wash narrows into a slot canyon that is eroded into the Navajo Sandstone. In some areas, the northern side of the canyon consists of basalt that originated from the Veyo Volcano. The channel is narrow and characterized by shallow sands and basalt cobbles overlying sandstone or by exposed sandstone. The channel width is about 10$20 \mathrm{ft}$ along its length. Calculated topographic gradients were 0.0165 and 0.0271 for the upper and lower parts, respectively.

\section{Data Collection}

Six boreholes were drilled at four sites in Sand Cove Wash (fig. 1) to collect cores to determine the vertical and spatial distribution of sediments in the wash and their hydrologic properties. A drill rig equipped with a 6-in-diameter hollow stem auger was used for drilling in unconsolidated alluvium and a 4-in-diameter rotary air bit was used for consolidated rock. Two of the sites had paired boreholes with each pair consisting of one borehole inside the channel of Sand Cove Wash and one outside. Boreholes at the other sites were located inside the channel. Core samples were collected at selected depths with a split-spoon sampler in unconsolidated alluvium and as a continuous core in sandstone. Nine to $13 \mathrm{ft}$ of fine alluvial sand was underlain by $50-70 \mathrm{ft}$ of fine silts and clays, beneath which was either Navajo Sandstone or basalt. Lithologic logs for the boreholes are contained in table 1.

Cores collected at selected depths were analyzed for specific conductance of leachates, particle-size distribution, and saturated vertical hydraulic conductivity. Analysis of particle-size distribution and hydraulic conductivity was done by Terra Tek of Salt Lake City, Utah.
Table 1. Lithologic logs of selected boreholes in Sand Cove Wash, Washington County, Utah

[Borehole location, altitude, and material: See figure 1 for location of boreholes; Thickness, in feet; Depth, total depth to bottom of interval, in feet below land surface]

\begin{tabular}{|c|c|c|}
\hline Borehole location, altitude, and material & Thickness & Depth \\
\hline \multicolumn{3}{|l|}{ SCBH1s Altitude 4,420 feet } \\
\hline Sand, fine with cobbles & 18.5 & 18.5 \\
\hline Clay, sandy brown with cobbles & 15.5 & 34.0 \\
\hline Clay, silty brown & 14.0 & 48.0 \\
\hline Clay, with basalt cobbles & 2.0 & 50.0 \\
\hline \multicolumn{3}{|l|}{ SCBH1d Altitude 4,420 feet } \\
\hline Sand, fine with cobbles & 13.5 & 13.5 \\
\hline Clay, silty brown and dry & 19.5 & 33.0 \\
\hline Clay, silty red and moist & 20.0 & 53.0 \\
\hline Clay, red with basalt cinders & 17.0 & 70.0 \\
\hline Basalt cobbles & 3.5 & 73.5 \\
\hline Basalt & 2.5 & 75.0 \\
\hline \multicolumn{3}{|l|}{ SCBH2 Altitude 4,350 feet } \\
\hline Sand, fine with gravel & 8.5 & 8.5 \\
\hline Clay, silty brown & 11.5 & 20.0 \\
\hline \multicolumn{3}{|l|}{ SCBH3 Altitude 4,340 feet } \\
\hline Sand, fine with gravel & 14.0 & 14.0 \\
\hline Clay, brown silty to sandy & 13.0 & 27.0 \\
\hline Clay, brown silty & 10.5 & 37.5 \\
\hline Clay, brown silty & 5.0 & 42.5 \\
\hline Clay, darker brown with silt & 19.5 & 62.0 \\
\hline Basalt & 1.0 & 63.0 \\
\hline \multicolumn{3}{|l|}{ SCBH4s Altitude 4,340 feet } \\
\hline Sand, fine with cobbles & 4.0 & 4.0 \\
\hline Sand, fine with coarse gravel & 3.5 & 7.5 \\
\hline Sand, fine with gravel & 8.0 & 15.5 \\
\hline Clay, silty brown with sand & 27.5 & 43.0 \\
\hline Clay/basalt, alternating layers & 22.5 & 65.5 \\
\hline Basalt & 4.5 & 70.0 \\
\hline Clay/basalt, alternating layers & 6.0 & 76.0 \\
\hline Basalt & 4.0 & 80.0 \\
\hline Clay/basalt, alternating layers & 4.0 & 84.0 \\
\hline Basalt & 11.0 & 95.0 \\
\hline \multicolumn{3}{|l|}{ SCBH4d Altitude 4,340 feet } \\
\hline Sand, fine with cobbles & 9.0 & 9.0 \\
\hline Clay, silty to sandy brown & 73.0 & 82.0 \\
\hline Sandstone, white, fractured & 82.0 & 164.0 \\
\hline
\end{tabular}




\section{Selected Hydrologic Data for Sand Cove Wash, Washington County, Utah}

\section{Specific Conductance}

Split-spoon core samplers have a removable "shoe" that holds the two halves of the device together. The shoe holds a small amount of core that is generally discarded. Shoe samples in this study were collected and used to evaluate the relative accumulation of solutes in the unsaturated zone. Areas with high unsaturated-zone solute accumulation generally indicate low rates of natural recharge (Allison and others, 1994; Cook and others, 1992; Scanlon, 1991). Samples were processed to dissolve salts from grain surfaces into aqueous phase leachates whose conductivity was then measured.

Leachates were extracted from core samples by first drying the samples in an oven for 24 hours at $105^{\circ} \mathrm{C}$. Then equal weights of dry sediment and deionized water were mixed and placed in a shaker for 24 hours. The resulting leachates were decanted into vials and the specific conductance of the decanted water was measured. Specific-conductance values of these leachates ranged from $23 \mu \mathrm{S} / \mathrm{cm}$ to $2,940 \mu \mathrm{S} / \mathrm{cm}$ (table 2). The relation of depth to specific conductance at the four drill sites is shown in figure 2. Specific-conductance values of the leachates generally were less than 500 $\mu \mathrm{S} / \mathrm{cm}$ except for those measured from borehole SCBH4s. This borehole is located about $200 \mathrm{ft}$ outside the wash and had measured leachate specificconductance values of as much as $2,940 \mu \mathrm{S} / \mathrm{cm}$. The high values were measured from samples obtained from the shallow part of the borehole (fig. 2) and are similar to shallow solute bulges observed at other sites in the

Table 2. Specific-conductance value of leachates from core samples collected in Sand Cove Wash, Washington County, Utah

[See figure 1 for borehole location; $\mu \mathrm{S} / \mathrm{cm}$, microsiemens per centimeter at 25 degrees Celsius]

\begin{tabular}{lcc}
\hline $\begin{array}{c}\text { Borehole } \\
\text { location }\end{array}$ & $\begin{array}{c}\text { Depth } \\
\text { (feet below land } \\
\text { surface) }\end{array}$ & $\begin{array}{c}\text { Specific } \\
\text { conductance } \\
(\mu \text { S/cm) }\end{array}$ \\
\hline SCBH1s & 14.0 & 285 \\
& 19.0 & 440 \\
& 24.0 & 110 \\
25.5 & 195 \\
44.0 & 90 \\
& 49.0 & 89 \\
& & \\
& 24.0 & 305 \\
& 25.5 & 150 \\
& 34.0 & 34 \\
& 35.5 & 115 \\
& 44.0 & 96 \\
& 54.0 & 90 \\
& 64.0 & 76
\end{tabular}

Table 2. Specific-conductance value of leachates from core samples collected in Sand Cove Wash, Washington County, Utah-Continued

\begin{tabular}{|c|c|c|}
\hline $\begin{array}{l}\text { Borehole } \\
\text { location }\end{array}$ & $\begin{array}{c}\text { Depth } \\
\text { (feet below land } \\
\text { surface) }\end{array}$ & $\begin{array}{c}\text { Specific } \\
\text { conductance } \\
(\mu \mathrm{S} / \mathrm{cm})\end{array}$ \\
\hline SCBH1d-Continued & 64.8 & 74 \\
\hline \multirow[t]{2}{*}{$\mathrm{SCBH} 2$} & 14.0 & 135 \\
\hline & 15.5 & 85 \\
\hline \multirow[t]{4}{*}{$\mathrm{SCBH} 3$} & 14.0 & 285 \\
\hline & 34.0 & 300 \\
\hline & 58.5 & 170 \\
\hline & 62.0 & 200 \\
\hline \multirow[t]{14}{*}{$\mathrm{SCBH} 4 \mathrm{~s}$} & 14.0 & 610 \\
\hline & 15.5 & 1,500 \\
\hline & 24.0 & 2,350 \\
\hline & 25.5 & 2,570 \\
\hline & 34.0 & 2,940 \\
\hline & 35.5 & 2,050 \\
\hline & 44.0 & 1,730 \\
\hline & 47.5 & 2,030 \\
\hline & 48.5 & 1,630 \\
\hline & 53.5 & 2,400 \\
\hline & 63.5 & 200 \\
\hline & 73.0 & 96 \\
\hline & 74.5 & 105 \\
\hline & 83.0 & 67 \\
\hline \multirow[t]{23}{*}{ SCBH4d } & 4.0 & 74 \\
\hline & 9.0 & 265 \\
\hline & 14.0 & 245 \\
\hline & 15.5 & 255 \\
\hline & 24.0 & 78 \\
\hline & 25.5 & 110 \\
\hline & 34.0 & 130 \\
\hline & 35.5 & 140 \\
\hline & 44.0 & 67 \\
\hline & 45.5 & 160 \\
\hline & 54.0 & 100 \\
\hline & 55.5 & 73 \\
\hline & 64.0 & 130 \\
\hline & 74.0 & 240 \\
\hline & 82.5 & 120 \\
\hline & 90.0 & 25 \\
\hline & 100.0 & 27 \\
\hline & 110.0 & 33 \\
\hline & 120.0 & 33 \\
\hline & 130.0 & 23 \\
\hline & 140.0 & 45 \\
\hline & 150.0 & 31 \\
\hline & 160.0 & 41 \\
\hline
\end{tabular}




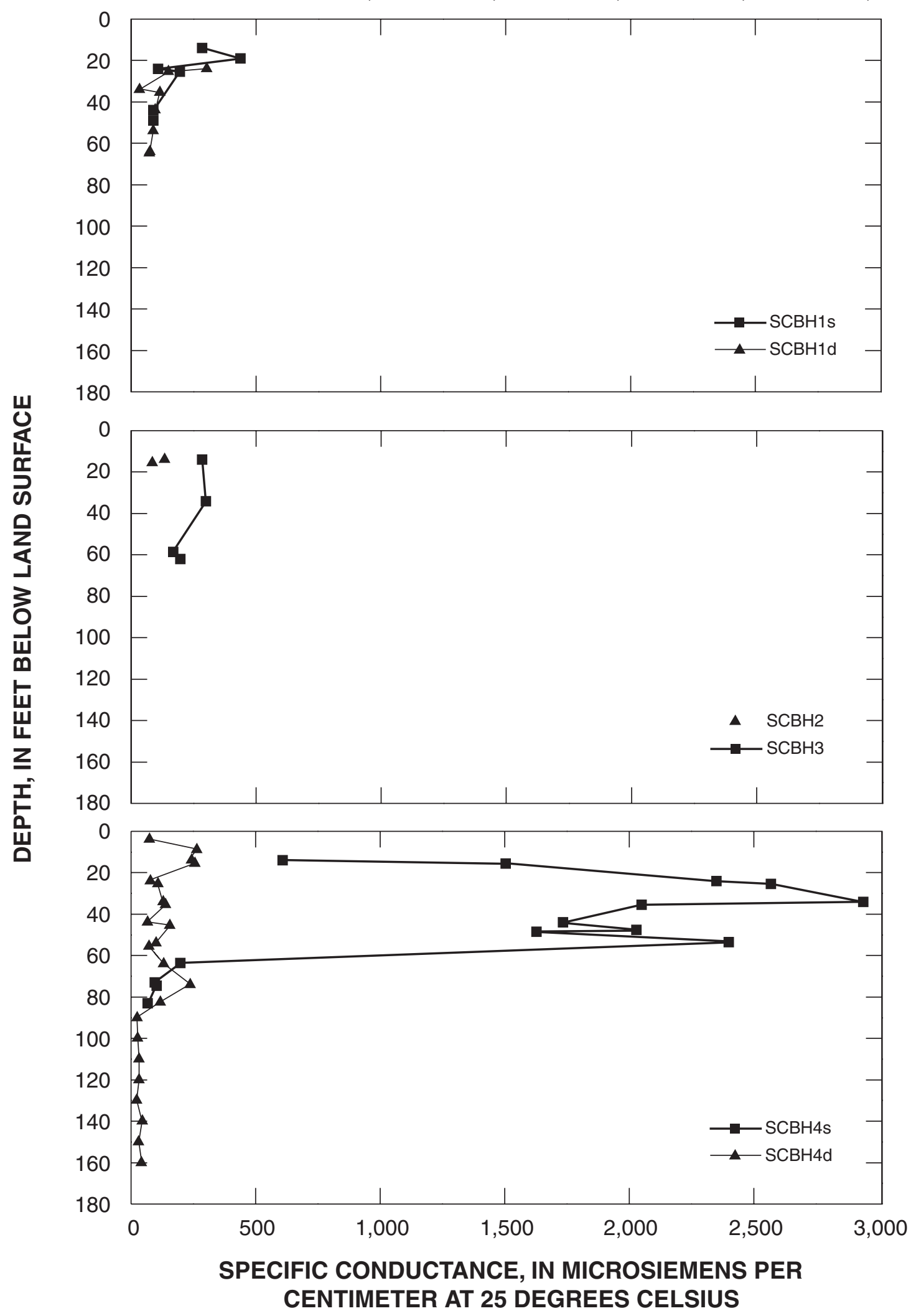

Figure 2. Relation of depth to specific conductance for leachates from core samples collected in Sand Cove Wash, Washington County, Utah. 


\section{Selected Hydrologic Data for Sand Cove Wash, Washington County, Utah}

southwestern United States (Scanlon, 1991; Phillips and others, 1988; Prudic, 1994).

\section{Particle-Size Distribution and Hydraulic Conductivity}

Particle-size distribution and vertical hydraulic conductivity were determined for selected samples. Particle-size distribution was determined by laser analysis and hydraulic conductivity by American Society for Testing and Materials (ASTM) method D5084. Three samples collected from two boreholes at depths of $4 \mathrm{ft}, 14$ $\mathrm{ft}$, and $34 \mathrm{ft}$ were analyzed and the results are shown in tables 3 and 4.

Saturated vertical hydraulic conductivity was determined for the three borehole samples by using the falling head permeameter method (ASTM method D2434). The three samples at depths of $4 \mathrm{ft}$ (fine sand), $14 \mathrm{ft}$ (coarse silt), and $34 \mathrm{ft}$ (coarse silt) had vertical hydraulic-conductivity values of $2.50,1.92 \times 10^{-} 4$, and $1.0 \times 10^{-2} \mathrm{ft} /$ day, respectively.

\section{Summary}

Hydrologic data collected in Sand Cove Wash in southwestern Utah to determine the vertical and spatial distribution of alluvial sediments and their hydrologic properties are compiled in this report. Six boreholes were drilled in or next to the wash. Lithologic logs of the boreholes generally indicate that 9 to $13 \mathrm{ft}$ of fine sand overlie 50-70 ft of fine silt and clay, which overlie Navajo Sandstone or basalt bedrock. Cores collected from selected depths were analyzed for specific conductance of leachates, particle-size distribution, and saturated vertical hydraulic conductivity. Specific-conductance values of leachates ranged from 23 to $2,940 \mu \mathrm{S} / \mathrm{cm}$. Vertical hydraulic-conductivity values measured in three samples were $2.50,1.92 \times 10^{-4}$, and $1.00 \times 10^{-2} \mathrm{ft} / \mathrm{d}$. The soil descriptions for the three samples were fine sand, coarse silt, and coarse silt, respectively.

Table 3. Particle-size distribution of alluvial deposits along Sand Cove Wash, Washington County, Utah

[See figure 1 for location of borehole. Description: Wentworth Classification]

\begin{tabular}{|c|c|c|c|c|c|c|c|c|c|c|c|c|c|c|c|c|}
\hline \multirow{3}{*}{$\begin{array}{l}\text { Borehole } \\
\text { location }\end{array}$} & \multirow{3}{*}{$\begin{array}{l}\text { Depth } \\
\text { (feet) }\end{array}$} & \multirow{3}{*}{ Description } & \multicolumn{14}{|c|}{$\begin{array}{l}\text { Particle-size distribution } \\
\text { (weight, in percent) }\end{array}$} \\
\hline & & & \multicolumn{8}{|c|}{ Sand } & \multicolumn{5}{|c|}{ Silt } & \multirow{2}{*}{$\begin{array}{c}\text { Clay } \\
\text { Total }\end{array}$} \\
\hline & & & Pebble & Granule & $\begin{array}{l}\text { Very } \\
\text { coarse }\end{array}$ & Coarse & Medium & Fine & Very fine & Total & Coarse & Medium & Fine & Very fine & Total & \\
\hline SCBH4d & 4.0 & Fine Sand & 0.00 & 0.00 & 0.00 & 0.19 & 34.19 & 50.03 & 8.79 & 93.20 & 1.68 & 1.19 & 1.06 & 1.05 & 4.98 & 1.83 \\
\hline SCBH3 & 14.0 & Coarse Silt & .00 & .00 & .00 & .00 & .93 & 10.27 & 19.25 & 30.45 & 24.00 & 19.48 & 10.43 & 6.44 & 60.35 & 9.18 \\
\hline SCBH3 & 34.0 & Coarse Silt & .00 & .00 & .00 & .00 & .00 & 2.96 & 18.20 & 21.16 & 25.07 & 18.27 & 12.12 & 9.28 & 64.74 & 14.11 \\
\hline
\end{tabular}

Table 4. Hydraulic properties of core samples collected from unconsolidated deposits in Sand Cove Wash, Washington County, Utah [See figure 1 for location of borehole. Millidarcy, 1 darcy equals $9.87 \times 10^{-13} \mathrm{~m}^{2}$ ]

\begin{tabular}{lccc}
\hline $\begin{array}{c}\text { Borehole } \\
\text { location }\end{array}$ & $\begin{array}{c}\text { Depth } \\
\text { (feet below } \\
\text { land surface) }\end{array}$ & $\begin{array}{c}\text { Average permeability } \\
\text { (millidarcies) }\end{array}$ & $\begin{array}{c}\text { Average vertical } \\
\text { hydraulic conductivity } \\
\text { (feet per day) }\end{array}$ \\
\hline SCBH4d & 4.0 & 903 & 2.50 \\
SCBH3 & 14.0 & .07 & $1.92 \times 10^{-4}$ \\
SCBH3 & 34.0 & 3.58 & $1.00 \times 10^{-2}$ \\
\hline
\end{tabular}




\section{References Cited}

Allison, G.B., Gee, G.W., and Tyler, S.W., 1994, Vadose-zone techniques for estimating groundwater recharge in arid and semiarid regions: Soil Science Society of America Journal, 58, no. 1, p. 6-14.

Cook, P.G., Walker, G.R., and Jolly, I.D., 1992, Spatial variability of groundwater recharge in a semiarid region: Journal of Hydrology, v. 111, p. 195-212.

Norton, A., 2004, Evaluation of an ephemeral wash for spring runoff storage, Washington County, Utah: University of Utah M.S. thesis, $77 \mathrm{p}$.

Phillips, F.M., Mattick, J.L., and Duval, T.A., 1988, Chlorine 36 and tritium from nuclear weapons fallout as tracers for long-term liquid movement in desert soils: Water Resources Research, 24, p. 1877-1891.

Prudic, D.E., 1994, Estimates of percolation rates and ages of water in unsaturated sediments at two Mohave Desert sites, California-Nevada: U.S. Geological Survey WaterResources Investigations Report 94-4160, 19 p.

Scanlon, B.R., 1991, Evaluation of moisture flux from chloride data in desert soils: Journal of Hydrology, 128, p. 137156. 